\title{
PEMODELAN REGRESI RIDGE ROBUST S,M, MM-ESTIMATOR DALAM PENANGANAN MULTIKOLINIERITAS DAN PENCILAN (Studi Kasus : Faktor-Faktor yang Mempengaruhi Kemiskinan di Jawa Tengah Tahun 2020)
}

\author{
Anggun Perdana Aji Pangesti ${ }^{1}$, Sugito ${ }^{2}$, Hasbi Yasin ${ }^{3}$ \\ ${ }^{1,2,3}$ Departemen Statistika, Fakultas Sains dan Matematika, Universitas Diponegoro
}

\begin{abstract}
The Ordinary Least Squares (OLS) is one of the most commonly used method to estimate linier regression parameters. If there is a violation of assumptions such as multicolliniearity especially coupled with the outliers, then the regression with OLS is no longer used. One method can be used to solved the multicollinearity and outliers problem is Ridge Robust Regression. Ridge Robust Regression is a modification of ridge regression method used to solve the multicolliniearity and using some estimators of robust regression used to solve the outlier, the estimator including : Maximum likelihood estimator (M-estimator), Scale estimator (S-estimator), and Method of moment estimator (MM-estimator). The case study can be used with this method is data with multicollinearity and outlier, the case study in this research is poverty in Central Java 2020 influenced by life expentancy, unemployment number, GRDP rate, dependency ratio, human development index, the precentage of population over 15 years of age with the highest education in primary school, mean years school. The result of estimation using OLS show that there is a multicollinearity and presence an outliers. Applied the ridge robust regression to case study prove that ridge robust regression can improve parameter estimation. The best ridge robust regression model is Ridge Robust Regression SEstimator. The influence value of predictor variabels to poverty is $73,08 \%$ and the MSE value is 0,00791 .
\end{abstract}

Keywords : Ordinary Least Square (OLS), Multicolliniearity, Ridge Regression, Outliers, Robust Regression, Ridge Robust Regression, Poverty

\section{PENDAHULUAN}

Kemiskinan merupakan salah satu permasalahan yang dihadapi setiap negara. Kemiskinan adalah kondisi ketidakmampuan ekonomi seseorang atau sekelompok untuk memenuhi hak-hak dasarnya untuk mempertahankan hidup dan bekerja. Jumlah penduduk miskin di Provinsi Jawa Tengah pada Maret 2020 mencapai 3.98 juta orang atau sebesar 11.41 persen (BPS, 2019). Ada banyak hal yang dapat mempengaruhi angka kemiskinan, dengan mengetahui faktor-faktor yang mempengaruhi kemiskinan maka dapat dilakukan upaya untuk menurunkan angka kemiskinan.

Analisis regresi linier berganda dengan menggunakan Metode Kuadrat Terkecil (MKT) merupakan salah satu metode yang dapat digunakan untuk mengetahui faktor-faktor yang mempengaruhi kemiskinan. Sebuah model regresi yang baik apabila dapat memenuhi semua asumsi yaitu normalitas, non-autokorelasi, homoskedastisitas dan multikolinieritas (Montgomery et al, 2012)

Salah satu pelanggaran asumsi yang terjadi adalah multikolinieritas dimana terdapat hubungan antara beberapa atau semua variabel prediktor dalam model regresi. Regresi ridge merupakan salah satu metode yang digunakan mengatasi multikolinieritas. (Montgomery et $a l$, 2012). Terjadinya pelanggaran asumsi dikarenakan terindikasi adanya pencilan. Pencilan merupakan kondisi dimana terdapat data yang nilainya berbeda jauh dengan data lainnya. Metode yang dapat menganalisis data yang terindikasi adanya pencilan adalah regresi robust. Regresi robust memiliki beberapa estimator antara lain Maximum likelihood estimator (M-estimator), Scale estimator (S-estimator), dan Method of moment estimator (MM-estimator) (Chen, 2002). 
Studi awal penelitian menggunakan regresi linier berganda dengan estimasi parameter Metode Kuadrat Terkecil, diketahui pada data kemiskinan terdapat pelanggaran asumsi berupa multikolinieritas dan heteroskedastisitas, dan terindikasi terdapat beberapa pencilan. Untuk menangani permasalahan tersebut diperlukan metode yang hasil estimasi parameternya stabil terhadap multikolinieritas dan pencilan. Metode tersebut adalah regresi ridge robust yang merupakan gabungan dari metode regresi ridge dan regresi robust (Lukman et al, 2014). Penelitian ini membahas analisis data kemiskinan tiap kabupaten/kota di Jawa Tengah dengan menggunakan metode regresi ridge robust $M$-estimator, S-estimator dan MM-estimator. Dari hasil analisis akan ditentukan model regresi ridge robust terbaik. Software yang digunakan dalam penelitian ini adalah software $R$.

\section{TINJAUAN PUSTAKA}

\subsection{Kemiskinan}

Kemiskinan merupakan salah satu permasalahan yang banyak dihadapi negara. kemiskinan adalah kondisi ekonomi seseorang atau sekelompok orang yang tidak terpenuhi hak-hak dasarnya untuk mempertahankan dan mengembangkan kehidupan yang bermatabat. Sedangkan penduduk miskin adalah penduduk yang memiliki rata-rata pengeluaran perkapita perbulan dibawah garis kemiskinan (BPS,2019)

\subsection{Analisis Regresi}

Menurut Montgomery et al. (2012), Model regresi berganda dinyatakan dalam bentuk persamaan :

$$
y_{i}=\beta_{0}+\beta_{1} x_{i 1}+\beta_{2} x_{i 2}+\cdots+\beta_{k} x_{i k}+\varepsilon_{i} ; i=1,2, \ldots, n
$$

\subsubsection{Estimasi Parameter Model Regresi Linier Berganda}

Menurut Montgomery et al. (2012), untuk mengestimasi parameter model regresi yaitu dengan meminimumkan jumlah kuadrat error yang dikenal dengan Metode Kuadrat Terkecil.

$$
S(\boldsymbol{\beta})=\sum_{i=1}^{n} \varepsilon_{i}^{2}=\boldsymbol{\varepsilon}^{\prime} \boldsymbol{\varepsilon}=(\boldsymbol{Y}-\boldsymbol{X} \boldsymbol{\beta})^{\prime}(\boldsymbol{Y}-\boldsymbol{X} \boldsymbol{\beta})
$$

Untuk mendapatkan estimator kuadrat terkecil $(\widehat{\boldsymbol{\beta}})$ yang meminimumkan $S(\boldsymbol{\beta})$ disyaratkan bahwa $\left.\frac{\partial S(\boldsymbol{\beta})}{\partial \boldsymbol{\beta}}\right|_{\boldsymbol{\beta}=\widehat{\boldsymbol{\beta}}}=0$. Turunan pertama dari $S(\boldsymbol{\beta})$ terhadap $\widehat{\boldsymbol{\beta}}$ adalah :

$$
\left.\frac{\partial S(\boldsymbol{\beta})}{\partial \boldsymbol{\beta}}\right|_{\boldsymbol{\beta}=\widehat{\boldsymbol{\beta}}}=-\mathbf{2} \boldsymbol{X}^{\prime} \boldsymbol{Y}+\mathbf{2} \boldsymbol{X}^{\prime} \boldsymbol{X} \widehat{\boldsymbol{\beta}}
$$

karena, $\left.\frac{\partial S(\boldsymbol{\beta})}{\partial \boldsymbol{\beta}}\right|_{\boldsymbol{\beta}=\widehat{\boldsymbol{\beta}}}=0$ maka

$$
\begin{aligned}
-2 X^{\prime} \boldsymbol{Y}+2 X^{\prime} \boldsymbol{X} \widehat{\boldsymbol{\beta}} & =0 \\
\widehat{\boldsymbol{\beta}} & =\left(X^{\prime} X\right)^{-1} X^{\prime} \boldsymbol{Y}
\end{aligned}
$$

\subsubsection{Uji Hipotesis Regresi Linear Berganda}

\section{a. Uji F}

Uji $\mathrm{F}$ digunakan untuk menguji ada atau tidaknya hubungan linier antara variabel respon $y$ dengan variabel prediktor $x_{1}, x_{2}, x_{3}, \ldots, x_{k}$ secara bersama-sama (Montgomery et al., 2012). Berikut langkah-langkahnya :

1. Hipotesis

$\mathrm{H}_{0}: \beta_{1}=\beta_{2}=\ldots=\beta_{\mathrm{k}}=0$ (tidak terdapat hubungan antara variabel respon $y$ dengan variabel prediktor $x_{j}$ secara bersama-sama)

$\mathrm{H}_{1}$ : terdapat $\beta_{\mathrm{j}} \neq 0$, dengan $\mathrm{j}=1,2, \ldots, \mathrm{k}$ (terdapat hubungan antara variabel respon $y$ dengan variabel prediktor $x_{j}$ secara bersama-sama)

2. Statistik uji 


$$
F_{\text {hitung }}=\frac{S S_{R} / k}{S S_{E} /(n-k-1)}=\frac{\mathrm{MSR}}{\mathrm{MSE}}
$$

3. Kriteria uji

$\mathrm{H}_{0}$ ditolak jika $F_{\text {hitung }}>F_{(\alpha, k, n-k-1)}$ atau $p$-value $<\alpha$

\section{b. Uji Koefisien Regresi secara Individual (Uji t)}

Pengujian ini digunakan untuk menguji ada atau tidaknya pengaruh yang signifikan antara masing-masing variabel prediktor terhadap model regresi linier.. Langkahnya :

1. Hipotesis

$\mathrm{H}_{0}: \beta_{\mathrm{j}}=0$ (koefisien parameter variabel $x_{j}$ tidak signifikan terhadap $y$ )

$\mathrm{H}_{1}: \beta_{\mathrm{j}} \neq 0$, (koefisien parameter variabel $x_{j}$ signifikan terhadap $y$ )

2. Statistik uji

$$
t=\frac{\widehat{\beta}_{j}}{\operatorname{Se}\left(\widehat{\beta}_{j}\right)}
$$

3. Kriteria uji

$$
\mathrm{H}_{0} \text { ditolak jika }\left|t_{\text {hitung }}\right|>t_{(\alpha / 2, n-k-1)} \text { atau } p \text {-value }<\alpha
$$

\subsubsection{Goodness of Fit (Ukuran Kecocokan Model)}

a. $\quad$ Koefisien Determinasi yang disesuaikan (Adjusted $\boldsymbol{R}^{\mathbf{2}}$ )

Menurut Gujarati (2003), $R^{2}$ merupakan suatu ukuran yang digunakan untuk mengetahui seberapa baik kecocokan dari suatu model regresi.

$$
R^{2}{ }_{A d j, k}=1-\frac{S S E /(n-k-1)}{S S T /{ }_{(n-1)}}=1-\frac{(n-1)}{(n-k-1)}\left(1-R^{2}\right)
$$

b. MSE (Mean Square Error)

Menurut Montgomery et al. (2012), dalam analisis regresi rumus MSE adalah MSE $=\frac{S S E}{n-k-1}$

\subsubsection{Uji Asumsi dalam Regresi Linier Berganda}

a. Uji Normalitas

Menurut Gujarati (2003), pada regresi linier klasik diasumsikan bahwa setiap $\varepsilon_{i}$ didistribusikan normal dengan $\varepsilon_{i} \sim N\left(0, \sigma^{2}\right)$. Salah satu uji formal yang dapat digunakan adalah Kolmogorov-Smirnov

$$
D=\sup _{e}\left|F_{0}(e)-S(e)\right|
$$

\section{b. Uji Autokorelasi}

Autokorelasi dapat didefinisikan sebagai korelasi antar anggota serangkaian pengamatan yang diurutkan waktu, dilambangkan dengan $E\left(\varepsilon_{i} \varepsilon_{j}\right)=0 \quad i \neq j$. Salah satu uji autokorelasi yang dapat dilakukan adalah dengan uji Durbin Watson.

$$
d=\frac{\sum_{i=2}^{i=n}\left(e_{i}-e_{i-1}\right)^{2}}{\sum_{i=2}^{i=n} e_{i}^{2}}
$$

\section{c. Uji Heteroskedastisitas}

Uji heteroskedastisitas digunakan untuk mengetahui pada model regresi terjadi ketidaksamaan varian dan residual atau tidak. Lambang homoskedastisitas adalah $E\left(\varepsilon_{i}^{2}\right)=\sigma^{2} i \neq j$. Menurut Gujarati (2003), untuk mengetahui ada tidaknya heteroskedastisitas dapat diperiksa dengan uji Glejser. Uji Glejser dilakukan dengan meregresikan nilai absolut residual $\left|e_{i}\right|$ terhadap variabel-variabel prediktor yang mempunyai hubungan erat dengan $\sigma^{2}$

$$
\left|e_{i}\right|=\beta_{0}+\beta_{1} x_{i 1}+\beta_{2} x_{i 2}+\cdots+\beta_{k} x_{i k}+v
$$

\subsection{Ukuran Pemusatan dan Penskalaan (Centering and Scaling)}

Menurut Kutner et al. (2005), perbedaan unit satuan pada model regresi perlu dilakukan standarisasi dengan rumus berikut: 


$$
\begin{array}{ll}
Y_{i}^{*}=\frac{y_{i}}{\sqrt{n-1}\left(S_{Y}\right)}=\frac{1}{\sqrt{n-1}}\left(\frac{Y_{i}-\bar{Y}}{S_{Y}}\right) \quad \operatorname{dimana} S_{Y} & =\sqrt{\frac{\sum_{i=1}^{n}\left(Y_{i}-\bar{Y}\right)^{2}}{n-1}} \\
Z_{i j}=\frac{x_{i j}}{\sqrt{n-1}\left(S_{j}\right)}=\frac{1}{\sqrt{n-1}}\left(\frac{X_{i j}-\bar{X}_{j}}{S_{j}}\right) & S_{j}=\sqrt{\frac{\sum_{i=1}^{n}\left(X_{i j}-\bar{X}_{j}\right)^{2}}{n-1}} \\
\text { untuk } i=1,2, \ldots, n ; j=1,2, \ldots, k &
\end{array}
$$

sehingga diperoleh model regres standar sebagai berikut:

$Y_{i}^{*}=\beta_{1}^{*} Z_{i 1}+\beta_{2}^{*} Z_{i 2}+\cdots+\beta_{k}^{*} Z_{i k}+\varepsilon_{i}$

hubungan estimator regresi bentuk standar dengan bentuk asli adalah:

$$
\beta_{j}=\left(\frac{s_{Y}}{s_{j}}\right) \beta_{j}^{*}, j=1,2, \ldots, k \text { dan } \beta_{0}=\bar{Y}-\beta_{1} \bar{X}_{1}-\beta_{2} \bar{X}_{2} \ldots-\beta_{k} \bar{X}_{k}
$$

\subsection{Multikolinieritas}

Multikolinieritas adalah kondisi dimana terdapat hubungan linier dari variabel prediktor. Model regresi yang baik adalah yang tidak terdapat multikolinieritas, untuk mengukur besarnya multikolinieritas menggunakan Variance Inflation Factors (VIF)

$$
\operatorname{VIF}\left(x_{j}\right)=\frac{1}{\left(1-R_{j}^{2}\right)}, \mathrm{i}=1,2, \ldots, \mathrm{n}
$$

Nilai VIF >10 menunjukkan multikolinearitas yang kuat (Montgomery et al., 2012).

\subsection{Pencilan}

Pencilan merupakan pengamatan yang nilainya ekstrim. Keberadaan pencilan dapat mengganggu akan tetapi menghapusnya bukan keputusan yang baik (Draper dan Smith, 1998). Metode yang dapat mendeteksi pencilan adalah Difference in Fit Standarized $\left(\right.$ DFFITS $\left._{i}\right)$

$$
\left(\text { DFFITS }_{i}\right)=t_{i}\left(\frac{h_{i i}}{1-h_{i i}}\right)^{\frac{1}{2}}
$$

Dimana $t_{i}$ adalah studentized deleted residual untuk kasus ke- $i$ dengan rumus:

$$
t_{i}=e_{i} \sqrt{\frac{n-p-1}{s S_{E}\left(1-h_{i i}\right)-e_{i}^{2}}}
$$

Data disebut pencilan jika $\mid$ DFFITS $\mid>1$ untuk data yang berukuran kecil $(\mathrm{n}<15)$ dan nilai $|D F F I T S|>2 \sqrt{p / n}$ untuk gugus data yang berukuran besar, dengan $p=k+1$, dan $\mathrm{n}$ adalah banyaknya observasi (Kutner et al., 2005)

\subsection{Regresi Ridge}

Menurut Dereny dan Rashwan (2011), model persamaan ridge didasarkan pada penambahan tetapan $\mathrm{K}$ pada diagonal utama matriks $\boldsymbol{X}^{\prime} \boldsymbol{X}$ sehingga model persamaan ridge menjadi:

$$
\boldsymbol{Y}=\boldsymbol{X} \boldsymbol{\beta}_{R}+\varepsilon
$$

Estimasi regresi ridge diperoleh dengan meminimumkan jumlah kuadrat error:

$$
\sum_{i=1}^{n} \varepsilon_{i}^{2}=\boldsymbol{\varepsilon}^{\prime} \boldsymbol{\varepsilon}=\left(\boldsymbol{Y}-\boldsymbol{X} \boldsymbol{\beta}_{\boldsymbol{R}}\right)^{\prime}\left(\boldsymbol{Y}-\boldsymbol{X} \boldsymbol{\beta}_{\boldsymbol{R}}\right)
$$

dengan kendala $\boldsymbol{\beta}_{\boldsymbol{R}}^{\prime} \boldsymbol{\beta}_{\boldsymbol{R}}=\boldsymbol{c}^{2}$. Bila $\boldsymbol{c}$ tetapan positif yang berhingga, dengan menggunakan metode pengali langrange maka diperoleh:

$$
L\left(\boldsymbol{\beta}_{\boldsymbol{R}}, K\right)=\left(\boldsymbol{Y}-\boldsymbol{X} \boldsymbol{\beta}_{\boldsymbol{R}}\right)^{\prime}\left(\boldsymbol{Y}-\boldsymbol{X} \boldsymbol{\beta}_{\boldsymbol{R}}\right)+K\left(\boldsymbol{\beta}_{\boldsymbol{R}}^{\prime} \boldsymbol{\beta}_{\boldsymbol{R}}-\boldsymbol{c}^{2}\right)
$$

sehingga diperoleh estimator regresi ridge yaitu:

$$
\boldsymbol{\beta}_{\boldsymbol{R}}=\left(\boldsymbol{X}^{\prime} \boldsymbol{X}+K \boldsymbol{I}\right)^{-1} \boldsymbol{X}^{\prime} \boldsymbol{Y}
$$

Dengan $K$ merupakan tetapan bias. 


\subsection{Regresi Robust}

Regresi robust merupakan metode regresi yang digunakan jika terdapat beberapa pencilan yang berpengaruh pada model sehingga hasil menjadi resistan terhadap pencilan (Draper dan Smith, 1998)

Menurut Chen (2002), regresi robust memiliki beberapa metode estimasi, diantaranya $M$-estimator, $S$-estimator dan MM-estimator.

\subsubsection{Robust M-Estimator}

Menurut Montgomery et al. (2012). M-estimator meminimumkan fungsi sisaan :

$$
\min _{\beta} \sum_{i=1}^{n} \rho\left(u_{i}\right)=\min _{\beta} \sum_{i=1}^{n} \rho\left(\frac{e_{i}}{s}\right)=\min _{\beta} \sum_{i=1}^{n} \rho\left(\frac{y_{i}-\sum_{j=0}^{k} x_{i j} \beta_{j}}{s}\right)
$$

dimana $s$ adalah skala estimasi robust. Estimasi $s$ yang digunakan adalah:

$$
s=\frac{M A D}{0,6475}=\frac{\text { median } \mid e_{i}-\text { median }\left(e_{i}\right) \mid}{0,6475} \text { dan } u_{i}=\frac{e_{i}}{s}
$$

Untuk mendapatkan estimasi parameter dengan mencari turunan parsial pertama dari $\rho$ terhadap $\beta_{j}(j=0,1, \ldots, k)$ disamakan dengan 0

$$
\sum_{i=1}^{n} x_{i j} \psi\left(\frac{y_{i}-\sum_{j=0}^{k} x_{i j} \beta_{j}}{s}\right)=0, \quad j=0,1, \ldots, k
$$

Draper dan Smith (1998) memberikan solusi dengan mendefinisikan fungsi pembobot :

$$
w\left(u_{i}\right)=\frac{\psi\left(\frac{y_{i}-\sum_{j=0}^{k} x_{i j} \beta_{j}}{s}\right)}{\left(\frac{y_{i}-\sum_{j=0}^{k} x_{i j} \beta_{j}}{s}\right)}
$$

dan $w_{i}=w\left(u_{i}\right)$. Kemudian estimasi persamaan dapat ditulis:

$$
\sum_{i=1}^{n} x_{i j} w_{i}\left(y_{i}-\sum_{j=0}^{k} x_{i j} \beta_{j}\right)=0 \quad, j=0,1, \ldots, k
$$

Kemudian diselesaikan dengan Iteratively Reweighted Least Square (IRLS). Iterasi akan berhenti jika $\widehat{\boldsymbol{\beta}}_{\boldsymbol{j}}$ konvergen yaitu selisih nilai $\widehat{\boldsymbol{\beta}}_{\boldsymbol{j}}^{(\boldsymbol{m}+\mathbf{1})}$ dan $\widehat{\boldsymbol{\beta}}_{\boldsymbol{j}}^{(\boldsymbol{m})}$ mendekati 0.

\subsubsection{Robust S-Estimator}

Salah satu cara untuk mengukur kerobustan estimator adalah dengan Breakdown point, S-estimator merupakan salah satu estimator yang memiliki nilai breakdown point yang tinggi. S-estimator didefinisikan:

$$
\hat{\beta}=\min _{\beta}\left(e_{1}(\boldsymbol{\beta}), e_{2}(\boldsymbol{\beta}) \ldots, e_{n}(\boldsymbol{\beta})\right)
$$

$e_{i}$ merupakan residual ke- $i$ dari $\beta$ dan $s\left(e_{1}, \ldots, e_{n}\right)$ didefinisikan sebagai solusi dari:

$$
\frac{1}{n} \sum_{i=1}^{n} \rho\left(\frac{e_{i}}{s}\right)=\frac{1}{1} \sum_{i=1}^{n} \rho\left(\frac{y_{i}-\sum_{j=0}^{k} x_{i j} \beta_{j}}{s}\right)=\delta
$$

Agar breakdown point 50\%, maka $\delta=E_{\phi} \rho\left(u_{i}\right)=0.1995$, dengan skala robust $(s)$ yang digunakan untuk iterasi pertama :

$$
s=\frac{M A D}{0,6475}=\frac{\text { median } \mid e_{i}-\text { median }\left(e_{i}\right) \mid}{0,6475}
$$

dan untuk iterasi berikutnya

$$
s=\sqrt{\frac{1}{n \delta} \sum_{i=1}^{n} w_{i} e_{i}^{2}}
$$

Dengan pembobot $w_{i}=w\left(u_{i}\right)=\frac{\rho\left(u_{i}\right)}{u_{i}{ }^{2}}$

Dengan menurunkan parsial pertama $\rho$ terhadap $\beta_{j}$ seperti pada $M$-Estimator sehingga didapatkan estimasi persamaan:

$$
\sum_{i=1}^{n} x_{i j} w_{i}\left(y_{i}-\sum_{j=0}^{k} x_{i j} \beta_{j}\right)=0 \quad, j=0,1, \ldots, k
$$


Kemudian diselesaikan dengan Iteratively Reweighted Least Square (IRLS). Iterasi akan berhenti jika $\widehat{\boldsymbol{\beta}}_{\boldsymbol{j}}$ konvergen yaitu selisih nilai $\widehat{\boldsymbol{\beta}}_{\boldsymbol{j}}^{(\boldsymbol{m}+\mathbf{1})}$ dan $\widehat{\boldsymbol{\beta}}_{\boldsymbol{j}}^{(\boldsymbol{m})}$ mendekati 0.

\subsubsection{Robust MM-Estimator}

Menurut Chen (2002), MM-estimator merupakan kombinasi antara estimator yang memiliki breakdownt point tinggi dan M-estimator yang memiliki efisiensi tinggi. Yohai dalam Stuart (2011) mendiskripsikan tiga tahapan MM-estimator :

1. Menentukan estimasi awal yang ditunjukkan $\widehat{\boldsymbol{\beta}}$ dengan estimator yang memiliki breakdown point tinggi, biasanya S-estimator

2. Menghitung residual dan skala M-estimator dengan $50 \%$ breakdown point. $s\left(e_{1}(\widehat{\boldsymbol{\beta}}), e_{2}(\widehat{\boldsymbol{\beta}}) \ldots, e_{n}(\widehat{\boldsymbol{\beta}})\right)$ dinotasikan $s_{n}$.

3. Menghitung estimasi parameter akhir dengan M-estimator, menggunakan turunan fungsi pengaruh $\psi\left(u_{i}\right)$ dan skala $s_{n}$ didapatkan dari langkah kedua.

\subsection{Regresi Ridge Robust}

Regresi ridge robust merupakan penggabungan dari metode regresi ridge dan regresi robust, perbedaan dengan regresi ridge biasa adalah pada penduga parameter yang digunakan. Penduga yang dihasilkan akan resisten terhadap pencilan.

Rumus penduga parameter regresi ridge robust adalah sebagai berikut:

$$
\widehat{\boldsymbol{\beta}}_{\boldsymbol{R} R}=\left(\boldsymbol{X}^{\prime} \boldsymbol{X}+K \boldsymbol{I}\right)^{-\mathbf{1}} \boldsymbol{X}^{\prime} \boldsymbol{Y}
$$

Menurut Dereny dan Rashwan (2011), salah satu cara menentukan $K$ dengan metode yang dikenalkan oleh Hoerl, Kennard, dan Balwin (HKB)

$$
K_{H K B}=\frac{k\left(M S E^{\text {Robust }}\right)}{\widehat{\boldsymbol{\beta}}^{\text {Robust }} \widehat{\boldsymbol{\beta}}^{\text {Robust }}}
$$

\section{METODE PENELITIAN}

\subsection{Sumber Data dan Variabel Penelitian}

Data yang digunakan adalah data sekunder, bersumber dari Provinsi Jawa Tnegah dalam Angka tahun 2021 dan Statistik Kesejahteraan Rakyat Jawa Tengah tahun 2020 yang dapat diakses https://jateng.bps.go.id/

\subsection{Variabel Penelitian}

$Y \quad$ : Kemiskinan

$\mathrm{X}_{1} \quad$ : Angka Harapan Hidup

$\mathrm{X}_{2} \quad$ : Jumlah Pengangguran

$\mathrm{X}_{3}$ : Laju PDRB

$\mathrm{X}_{4} \quad$ : Rasio Ketergantungan

$\mathrm{X}_{5} \quad$ : Indeks Pembangunan Manusia (IPM)

$\mathrm{X}_{6}$ : Persentase Penduduk Berusia lebih dari 15 Tahun dengan Pendidikan Tertinggi SD

$\mathrm{X}_{7} \quad$ : Rata-rata Lama Sekolah

\subsection{Tahapan Analisis Data}

1. Mengumpulkan data.

2. Menentukan variabel terikat dan variabel bebas.

3. Melakukan standarisasi data dengan Transfomasi Korelasi

4. Mengestimasi koefisien regresi $\widehat{\boldsymbol{\beta}}$ menggunakan Metode Kuadrat Terkecil.

5. Melakukan Uji F dan Uji t

6. Menghitung Adjusted $R^{2}$ dan MSE.

7. Melakukan uji multikolinearitas dengan melihat nilai VIF. 
8. Melakukan pendeteksian pencilan dengan $\operatorname{DFFITS}_{i}$.

9. Mengestimasi nilai $\widehat{\boldsymbol{\beta}}^{\text {(robust) }}$ ) dengan menggunakan metode Regresi Robust dengan pembobot tukey's-bisquare

10. Menghitung nilai $\widehat{\boldsymbol{\beta}}_{\boldsymbol{R} \boldsymbol{R}}$ pada metode Regresi Ridge Robust

11. Melakukan uji $\mathrm{F}$ dan uji $\mathrm{t}$ untuk model regresi ridge robust

12. Menghitung Adjusted $R^{2}$ dan MSE untuk model regresi ridge robust.

13. Membandingkan nilai Adjusted $R^{2}$ dan MSE model Regresi MKT dan Regresi Ridge Robust untuk mendapatkan model terbaik

\section{HASIL DAN PEMBAHASAN}

\subsection{Regresi Linier Berganda}

Pada awal penelitian dilakukan analisis regresi linier berganda dengan estimasi parameter menggunakan Metode Kuadrat Terkecil.

\subsubsection{Estimasi Parameter Regresi}

Dari hasil output didapatkan model regresi linier berganda sebagai berikut:

$\hat{y}=-0,157531 Z_{1}+0,478338 Z_{2}+0,099946 Z_{3}+0,250985 Z_{4}-0,095399 Z_{5}+$ $0,049871 Z_{6}-0,117738 Z_{7}$

\subsubsection{Uji Signifikansi Parameter}

a. Uji F

1. Hipotesis

$H_{0}: \beta_{1}=\beta_{2}=\beta_{3}=\beta_{4}=\beta_{5}=\beta_{6}=\beta_{6=} 0$

$\mathrm{H}_{1}$ : terdapat $\beta_{\mathrm{j}} \neq 0, \mathrm{j}=1,2,3,4,5,6,7$

2. Taraf signifikansi

$\alpha=5 \%=0,05$

3. Statistik uji

$F_{\text {hitung }}=9,81$ dan $p$-value $=0,000005$

4. Kriteria uji

$\mathrm{H}_{0}$ ditolak jika $F_{\text {hitung }}>\left(F_{(5 \% ; 6 ; 28)}=2,45\right)$ atau $p$-value $<\alpha(0,05)$

5. Keputusan

$\mathrm{H}_{0}$ ditolak karena $F_{\text {hitung }}=5,655063>\left(F_{(5 \% ; 6 ; 27)}=2,37\right)$ atau $p$-value $(0,000005)<\alpha(0,05)$

6. Kesimpulan

Pada taraf signifikansi 5\% dapat disimpulkan bahwa terdapat hubungan antara variabel respon kemiskinan dengan variabel prediktor (AHH, pengangguran, laju PDRB, rasio ketergantungan, IPM, presentase penduduk berusia lebih dari 15 tahun dengan pendidikan tertinggi SD, rata-rata lama sekolah) secara bersama-sama.

b. Uji Koefisien Regresi secara Individual (Uji t)

1. Hipotesis

$\mathrm{H}_{0}: \beta_{\mathrm{j}}=0$, dimana $\mathrm{j}=1,2,3,4,5,6,7$

$\mathrm{H}_{1}: \beta_{\mathrm{j}} \neq 0$, dimana $\mathrm{j}=1,2,3,4,5,6,7$

2. Taraf signifikansi

$\alpha=5 \%=0,05$

3. Statistik uji

Disajikan pada Tabel 1.

4. Kriteria uji

$\mathrm{H}_{0}$ ditolak jika $\left|t_{\text {hitung }}\right|>\left(t_{(2,5 \% ; 27)}=2,052\right)$ atau $p$-value $<\alpha(0,05)$

5. Keputusan 
Tabel 1. Tabel Uji t Regresi Linier Berganda dengan MKT

\begin{tabular}{cccc}
\hline Variabel & $\boldsymbol{t}_{\boldsymbol{h i t u n g}}$ & $\boldsymbol{p}$-value & Keputusan \\
\hline $\boldsymbol{Z}_{\mathbf{1}}$ & $-0,891753$ & 0,380404 & $\mathrm{H}_{0}$ diterima \\
$\boldsymbol{Z}_{\mathbf{2}}$ & 3,977133 & 0,000470 & $\mathrm{H}_{0}$ ditolak \\
$\boldsymbol{Z}_{\mathbf{3}}$ & 0,925263 & 0,363026 & $\mathrm{H}_{0}$ diterima \\
$\boldsymbol{Z}_{\mathbf{4}}$ & 1,657337 & 0,109028 & $\mathrm{H}_{0}$ diterima \\
$\boldsymbol{Z}_{\mathbf{5}}$ & $-0,203321$ & 0,840409 & $\mathrm{H}_{0}$ diterima \\
$\boldsymbol{Z}_{\mathbf{6}}$ & 0,217616 & 0,829364 & $\mathrm{H}_{0}$ diterima \\
$\boldsymbol{Z}_{\mathbf{7}}$ & $-0,260652$ & 0,796339 & $\mathrm{H}_{0}$ diterima \\
\hline
\end{tabular}

6. Kesimpulan

Pada taraf signifikansi 5\% hanya koefisien parameter jumlah pengangguran $\left(Z_{2}\right)$ yang berpengaruh signifikan terhadap kemiskinan $(y)$. Sedangkan koefisien parameter $\mathrm{AHH}\left(Z_{1}\right)$, laju $\operatorname{PDRB}\left(Z_{3}\right)$, rasio ketergantungan $\left(Z_{4}\right)$, IPM $\left(Z_{5}\right)$, presentase penduduk berusia lebih dari 15 tahun dengan pendidikan tertinggi SD $\left(Z_{6}\right)$, rata-rata lama sekolah $\left(Z_{7}\right)$ tidak berpengaruh signifikan terhadap kemiskinan $(y)$. Karena ada beberapa variabel bebas yang tidak berpengaruh, maka dengan menggunakan metode backward diperoleh model baru yaitu :

$$
\hat{y}=0,497273 Z_{2}-0,544549 Z_{7}
$$

\subsubsection{Goodness Of Fit}

a. $\quad$ Adjusted $\boldsymbol{R}^{2}$

$R^{2}{ }_{\text {Adj }, k}=0,638253$

Artinya Berdasarkan nilai tersebut maka berarti kemiskinan dipengaruhi oleh $\mathrm{AHH}$ dan rata-rata lama sekolah sebesar $63,83 \%$ dan sisanya $36,17 \%$ dipengaruhi oleh faktor lain.

b. MSE

MSE $=0,010639$

\subsubsection{Uji Asumsi dalam Regresi Linier Berganda}

a. Uji Normalitas

Nilai $\mathrm{D}=0,074594$ dan $p$-value $=0,9889$

Kesimpulan : Pada taraf signifikansi 5\% residual data berdistribusi normal

b. Uji Autokorelasi

Nilai $d=1,76392$

$d_{U}(1,5838) \leq d(1,76392) \leq 4-d_{U}(2,4162)$

Kesimpulan : Pada taraf signifikansi 5\%, tidak ada autokorelasi positif atau negatif antar residual.

c. Uji Heteroskedastisitas

Tabel 2. Tabel Uji Glejser

\begin{tabular}{cccc}
\hline Variabel & $\boldsymbol{t}_{\text {hitung }}$ & $\boldsymbol{p}$-value & Keputusan \\
\hline $\boldsymbol{Z}_{2}$ & 2,593929 & 0,014952 & $\mathrm{H}_{0}$ ditolak \\
$\boldsymbol{Z}_{7}$ & $-0,3871589$ & 0,701201 & $\mathrm{H}_{0}$ diterima
\end{tabular}

Kesimpulan : Pada taraf signifikansi 5\% terdapat heteroskedastisitas 
4.2 Pendeteksian Multikolinieritas dan Pencilan

a. Pendeteksian Multikolinieritas

Tabel 2. Nilai VIF

\begin{tabular}{ccc}
\hline Variabel & VIF & Keterangan \\
\hline $\boldsymbol{Z}_{\mathbf{1}}$ & 2,984893 & VIF $<10$ \\
$\boldsymbol{Z}_{\mathbf{2}}$ & 1,383600 & VIF $<10$ \\
$\boldsymbol{Z}_{\mathbf{3}}$ & 1,116037 & VIF $<10$ \\
$\boldsymbol{Z}_{\mathbf{4}}$ & 2,193583 & VIF $<10$ \\
$\boldsymbol{Z}_{\mathbf{5}}$ & 21,057710 & VIF $>10$ \\
$\boldsymbol{Z}_{\mathbf{6}}$ & 5,023295 & VIF $<10$ \\
$\boldsymbol{Z}_{\mathbf{7}}$ & 19,516113 & VIF $>10$ \\
\hline
\end{tabular}

Kesimpulan : Pada taraf signifikansi 5\% terjadi multikolinieritas pada variabel IPM $\left(Z_{5}\right)$ dan rata-rata lama sekolah $\left(Z_{7}\right)$

b. Pendeteksian Pencilan

Dikarenakan jumlah data $(n)=35$ termasuk gugus data besar, maka batas suatu data dikatakan sebagai pencilan jika nilai $\mid$ DFFITS $\mid>2 \sqrt{(k+1) / n}$ dengan $k=7$, sehingga $\mid$ DFFITS $\mid>0,9561829$. Sehingga diperoleh 4 pencilan terdeteksi, yaitu data ke 1, 28, 29 dan 33 .

4.3. Regresi Ridge Robust M-estimator

4.3.1. Estimasi Parameter Regresi Robust M-estimator

Model regresi robust M-estimator yang didapatkan setelah proses 27 kali iterasi adalah sebagai berikut :

$\hat{y}=0,008566-0,205064 Z_{1}+0,585185 Z_{2}+0,136933 Z_{3}+0,241089 Z_{4}-$ $0,264145 Z_{5}-0,040626 Z_{6}-0,004172 Z_{7}$

\subsubsection{Estimasi Parameter Regresi Ridge Robust-MM}

Pada output regresi ridge robust M-estimator dengan nilai $K=0,077646$ didapatkan model Regresi Ridge Robust M-estimator adalah sebagai berikut:

$\hat{y}=0,461210 Z_{2}+0,256313 Z_{4}-0,3459$
4.4. $\quad$ Regresi Ridge Robust S-estimator

4.4.1. Estimasi Parameter Regresi Robust S-estimator

Model regresi robust S-estimator yang didapatkan setelah proses 34 kali iterasi adalah sebagai berikut :

$\hat{y}=0,017040-0,207593 Z_{1}+0,677475 Z_{2}+0,141624 Z_{3}+0,069428 Z_{4}-$ $0,264423 Z_{5}-0,060280 Z_{6}-0,064634 Z_{7}$

\subsubsection{Estimasi Parameter Regresi Ridge Robust S-estimator}

Pada output regresi ridge robust $S$-estimator dengan nilai $K=0,0076887$ didapatkan model Regresi Ridge Robust $S$-estimator adalah sebagai berikut:

$$
\hat{y}=-0,180450 Z_{1}+0,461065 Z_{2}+0,104639 Z_{3}+0,2551741 Z_{4}-0,2360846 Z_{7}
$$

\subsection{Regresi Ridge Robust MM-estimator}

\subsubsection{Estimasi Parameter Regresi Robust MM-estimator}

Model regresi robust MM-estimator yang didapatkan setelah proses 34 kali iterasi dengan $S$-estimator dan 12 kali iterasi dengan $M$-estimator adalah sebagai berikut :

$\hat{y}=0,023327-0,108132 Z_{1}+0,826108 Z_{2}+0,176386 Z_{3}+0,173314 Z_{4}-$ $0,254300 Z_{5}+0,071576 Z_{6}+0,112614 Z_{7}$ 


\subsubsection{Estimasi Parameter Regrei Ridge Robust MM-estimator}

Pada output regresi ridge robust MM-estimator dengan nilai $K=0,032588$ didapatkan model Regresi Ridge Robust MM-estimator adalah sebagai berikut:

$$
\hat{y}=0,461706 Z_{2}+0,256303 Z_{4}-0,346274 Z_{7}
$$

\subsection{Pemilihan Model Regresi Ridge Robust Terbaik}

Sebelumnya model regresi harus dikembalikan ke dalam bentuk variabel asli, didapatkan empat model regresi sebagai berikut:

a. Model regresi linier berganda dengan estimasi parameter menggunakan Metode

Kuadrat Terkecil yaitu:

$\hat{y}=295,212895+0,001488 X_{2}-29,636952 X_{7}$

b. Model regresi linier berganda dengan estimasi parameter menggunakan Regresi

Ridge Robust M-estimator yaitu:

$\hat{y}=14,472737+0,001380 X_{2}+4,234321 X_{4}-18,827703 X_{7}$

c. Model regresi linier berganda dengan estimasi parameter menggunakan Regresi

Ridge Robust S-estimator yaitu:

$\hat{y}=473.216057-6,635838 X_{1}+0,001380 X_{2}+4,126659 X_{3}+4,215507 X_{4}-12,848849 X_{7}$

d. Model regresi linier berganda dengan estimasi parameter menggunakan Regresi

Ridge Robust MM-estimator yaitu:

$\hat{y}=14,571856+0,001382 X_{2}+4,234156 X_{4}-18.845881 X_{7}$

Pemilihan metode terbaik didasarkan pada besarnya nilai Adjusted $R^{2}$ dan MSE, disajikan dalam Tabel 3.

Tabel 3. Tabel Pembanding Regresi (MKT) dan Regresi Ridge Robust

\begin{tabular}{ccc}
\hline & Adjusted $^{\mathbf{2}}$ & MSE \\
\hline Metode Kuadrat Terkecil & 0,638253 & 0,010639 \\
Ridge Robust M-estimator & 0,645562 & 0,010425 \\
Ridge Robust S-estimator & 0,730798 & 0,007918 \\
Ridge Robust MM-estimator & 0,642049 & 0,010528 \\
\hline
\end{tabular}

Kriteria pemilihan model regresi robust terbaik yaitu mempunyai $R_{A d j, k}^{2}$ terbesar dan nilai MSE terkecil. Dari Tabel 3, disimpulkan bahwa model terbaik adalah Regresi Ridge Robust S-estimator

$\hat{y}=473.216057-6,635838 X_{1}+0,001380 X_{2}+4,126659 X_{3}+4,215507 X_{4}-$ $12,848849 X_{7}$

dengan nilai Adjusted $R^{2}$ terbesar yaitu 0,730798 dan MSE terkecil yaitu 0,007918. Selain itu, terdapat lebih banyak variabel prediktor yang signifikan terhadap variabel respon.

5. KESIMPULAN

Berdasarkan hasil dan pembahasan dalam pemodelan kemiskinan di Jawa Tengah tahun 2020, diperoleh kesimpulan sebagai berikut :

1. Estimasi parameter pertama menggunakan MKT, di mana pada model yang diperoleh asumsi homoskedastisitas dan multikolinieritas tidak terpenuhi. Terdapat 2 variabel dengan masalah multikolinieritas dan terdapat 4 buah pencilan. Oleh karena itu dilakukkan penanganan dengan metode regresi ridge robust.. Setelah dilakukan estimasi parameter menggunakan Regresi Ridge Robust S, M, MMestimator, lalu dicari model terbaik dengan membandingkan nilai Adjusted $R^{2}$ dan MSE. Model terbaik yang diperoleh yaitu dengan menggunakan Regresi Ridge Robust S-estimator. Model yang diperoleh sebagai berikut : 
$\hat{y}=473.216057-6,635838 X_{1}+0,001380 X_{2}+4,126659 X_{3}+4,215507 X_{4}-$ $12,848849 X_{7}$

2. Kemiskinan di Jawa Tengah tahun 2020 yang dipengaruhi oleh AHH, pengangguran, laju PDRB, rasio ketergantungan, dan rata-rata lama sekolah sebesar 73,08\% dengan nilai MSE yaitu 0,007081.

\section{DAFTAR PUSTAKA}

BPS. (2019). Provinsi Jawa Tengah dalam Angka tahun 2019. Semarang : Badan Pusat Statistik Jawa Tengah .

Chen, C. (2002). Robust Regression and Outlier Detection with ROBUSTREG Procedure . Sugi 27, Paper 265-27.

Dereny, M., \& Rashwan, N. I. (2011). Solving Multicolliniearity Problem Using Ridge Regression Models. Int. J Contemp. Math Sciences, Vol. 6(No. 12), 585-600.

Draper, N. R., \& Smith, H. (1998). Aplied Regression Analysis Third Edition. USA: John Wiley and Sons, Inc.

Gujarati, D. N. (2003). Basic Econometrics Fourth Edition. New York: The McGraw-Hill Companies.

Kutner, M. H., Nachtsheim , C. J., Neter , J., \& Li , W. (2005). Applied Linier Statistical Models. New York : The McGraw-Hill Comapanies .

Lukman, A., Arowolo, O., \& Ayinde , K. (2014). Some Robust Ridge Regression for Handling Multicollinearity and Outlier. International Journal of Sciences : Basic and Applied Research, Vol. 16(No. 2), 192-202.

Montgomery, D. C., Peck, E. A., \& Vining, G. G. (2012). Introduction To Linier Regression Analysis Fifth Edition. New Jersey: John Wiley and Sons, Inc. 